Article

\title{
Numerical Simulation of an Out-Vessel Loss of Coolant from the Breeder Primary Loop Due to Large Rupture of Tubes in a Primary Heat Exchanger in the DEMO WCLL Concept
}

\author{
Francesco Galleni ${ }^{1, * \mathbb{C}}$, Marigrazia Moscardini ${ }^{1}$, Andrea Pucciarelli ${ }^{1} \mathbb{(}$, Maria Teresa Porfiri ${ }^{2}$ \\ and Nicola Forgione ${ }^{1}$ \\ 1 Laboratory of Numerical Simulations for Nuclear Thermal-Hydraulics, Department of Civil and Industrial \\ Engineering, University of Pisa, 56122 Pisa, Italy; marigrazia.moscardini@dici.unipi.it (M.M.); \\ andrea.pucciarelli@dici.unipi.it (A.P.); nicola.forgione@unipi.it (N.F.) \\ 2 ENEA-CR Frascati, Dipartimento Fusione e Tecnologie per la Sicurezza Nucleare, 00044 Roma, Italy; \\ mariateresa.porfiri@enea.it \\ * Correspondence: francescog.galleni@dici.unipi.it
}

check for updates

Citation: Galleni, F.; Moscardini, M.; Pucciarelli, A.; Porfiri, M.T.; Forgione, N. Numerical Simulation of an Out-Vessel Loss of Coolant from the Breeder Primary Loop Due to Large Rupture of Tubes in a Primary Heat Exchanger in the DEMO WCLL Concept. Energies 2021, 14, 6916. https://doi.org/10.3390/en14216916

Academic Editor: Hyungdae Kim

Received: 17 August 2021

Accepted: 18 October 2021

Published: 21 October 2021

Publisher's Note: MDPI stays neutral with regard to jurisdictional claims in published maps and institutional affiliations.

Copyright: (c) 2021 by the authors. Licensee MDPI, Basel, Switzerland. This article is an open access article distributed under the terms and conditions of the Creative Commons Attribution (CC BY) license (https:/ / creativecommons.org/licenses/by/ $4.0 /)$.
Abstract: This work presents a thermohydraulic analysis of a postulated accident involving the rupture of the breeder primary cooling loop inside a heat exchanger (once through steam generator). After the detection of the loss of pressure inside the primary loop, a plasma shutdown is actuated with a consequent plasma disruption, isolation of the secondary loop, and shutoff of the pumps in the primary; no other safety counteractions are postulated. The objective of the work is to analyze the pressurization of the primary and secondary sides to show that the accidental overpressure in the two sides of the steam generators is safely accommodated. Furthermore, the effect of the plasma disruption on the FW, in terms of temperatures, should be analyzed. Lastly, the time transients of the pressures and temperatures in the HX and BB for a time span of up to $36 \mathrm{~h}$ should be obtained to assess the effect of the decay heat over a long period. A full nodalization of the OTSG was realized together with a simplified nodalization of the whole PHTS BB loop. The code utilized was MELCOR for fusion version 1.8.6. The accident was simulated by activating a flow path which directly connected one section of the primary with the parallel section of the secondary side. It is shown here that the pressures and the temperatures inside the whole PHTS system remain below the safety thresholds for the whole transient.

Keywords: WCLL-BB; MELCOR; PHTS; safety analysis; DEMO

\section{Introduction}

In the Roadmap to Fusion Electricity Horizon 2020, the European DEMOnstration Fusion Reactor (DEMO) is expected to be a nuclear fusion power plant with the aim of showing the feasibility of the production of electrical power through the conversion of around $2 \mathrm{GW}_{\mathrm{th}}$, generated continuously by the fusion reaction. The operational sequence is a pulsed operation, which consists of 11 pulses per day; each pulse comprises a burn time of $2 \mathrm{~h}$ (power pulse period; $100 \%$ of fusion power) and a dwell time of $10 \mathrm{~min}$ (1\% of fusion power generated due to the decay heat) $[1,2]$.

The work presented here aims to investigate the consequences of a loss of coolant accident in the primary heat transport system (PHTS) of the water-cooled lithium lead (WCLL) breeding blanket (BB) DEMO concept [2-4]. In particular, the objective of this work is the simulation of a rupture of pipes of the primary system into the PCS (power conversion system or secondary system) inside the once through steam generator (OTSG) which acts as interface between the two systems [5-7]. In normal operations, the energy transferred from the breeding zone (BZ) and from the first wall (FW) to PCS through steam generators is used to produce the main steam at condition suitable to feed the steam turbine. 
The postulated accident foresees the rupture of the primary cooling loop inside the OTSG with a discharge of primary coolant in the secondary side.

In this work, a detailed nodalization of the primary and secondary system of the OTSG is presented together with a simplified nodalization of the whole BZ loop. A connection between the two sides of the OTSG is created in order to simulate the LOCA scenario, which comprises a mitigated plasma disruption, and the results of the consequent transients are analyzed and discussed.

The nodalization of the involved systems was created with MELCOR for fusion 1.8.6, and all the simulations were performed with the same code. The MELCOR code has been under development for fusion applications for many decades [8,9]. Chiefly because of its capabilities of assessing thermal-hydraulic transients of fusion reactor systems and the transport of radionuclides, MELCOR was chosen, together with other system thermal hydraulics codes, to be used to perform safety analyses for the ITER project and, consequently, for the DEMO project [10]. Especially in the last 10 years, MELCOR was widely used for accident analysis related to ITER reactor safety and in the preliminary design phase of the DEMO reactor ([11-17], among many others).

\section{DEMO WCLL-BB PHTS System}

\subsection{General Parameters and Power Data}

The thermodynamic cycle used as reference for the design of the WCLL BB PHTS DEMO reactor was mainly based on parameters similar to pressurized water reactors: the coolant was water at $15.5 \mathrm{MPa}$ with inlet and outlet temperatures equal to $295{ }^{\circ} \mathrm{C}$ and $328^{\circ} \mathrm{C}$, respectively [3,7-9]. The main working parameters of the BB PHTS are given in Table 1, whilst the power parameters are reported in Table 2. Furthermore, Table 3 collects the mass flow rates of the FW and the BZ cooling systems. All the parameters and characteristics summarized here can be found in several technical and published studies [18].

Table 1. WCLL DCD BOP BB cooling system parameters [3].

\begin{tabular}{ccc}
\hline Description & Units & Parameters \\
\hline Typology of coolant & $\mathrm{MPa}$ & Water \\
Pressure & ${ }^{\circ} \mathrm{C}$ & 15.5 \\
Temperature range & $\mathrm{kg} / \mathrm{m}^{3}$ & $295-328$ \\
Coolant density (average) & $\mathrm{MPa}$ & 701.3 \\
Design pressure & ${ }^{\circ} \mathrm{C}$ & 17.8 \\
Design temperature & $\mathrm{kg} / \mathrm{s}$ & 345 \\
Total flow rate & $\mathrm{kg} / \mathrm{s}$ & 9936.0 \\
FW flow rate & & 17.8 \\
Inboard (IB) blanket & $\mathrm{kg} / \mathrm{s}$ & 35.5 \\
Outboard (OB) blanket & & 48.2 \\
BZ flow rate & & 127.5 \\
IB blanket & & \\
OB blanket & &
\end{tabular}

Table 2. DEMO and WCLL DCD BOP BB power balance [3].

\begin{tabular}{ccc}
\hline Description & Unit & WCLL 2018 Design \\
\hline Total nuclear heating & MW & 1650.3 \\
Total FW Heat Flux & MW & 272.7 \\
Neutron Wall Load & MW & 167.0 \\
Total FW power & MW & 439.8 \\
Total BZ power & MW & 1483.2 \\
Total power & MW & 1923.2 \\
\hline
\end{tabular}


Table 3. WCLL DCD BOP BB power and coolant flow rates (TD 295-328 ${ }^{\circ} \mathrm{C}$ ) [3].

\begin{tabular}{ccccccc}
\hline Description & \multicolumn{3}{c}{ Power (MW) } & \multicolumn{3}{c}{ Mass Flow Rate (kg/s) } \\
\hline--- & Total & FW & BZ & Total & FW & BZ \\
\hline $\begin{array}{c}\text { IB } \\
\text { segment }\end{array}$ & 12.780 & 3.449 & 9.331 & 66.0 & 17.8 & 48.2 \\
$\begin{array}{c}\text { IB sector } \\
\text { Total }\end{array}$ & 25.560 & 6.898 & 18.662 & 132.0 & 35.6 & 96.4 \\
$\begin{array}{c}\text { IB sectors } \\
\quad(\mathbf{1 6 )}\end{array}$ & 409.960 & 110.368 & $\mathbf{2 9 8 . 5 9 2}$ & 2112.0 & 569.6 & 1542.4 \\
$\begin{array}{c}\text { OB } \\
\text { segment }\end{array}$ & 31.545 & 6.867 & 24.678 & 163.0 & 35.5 & 127.5 \\
$\begin{array}{c}\text { OB sector } \\
\text { Total }\end{array}$ & 94.635 & 20.601 & 74.034 & 489.0 & 106.5 & 382.5 \\
$\begin{array}{c}\text { OB sectors } \\
\mathbf{( 1 6 )}\end{array}$ & 1514.160 & 329.616 & $\mathbf{1 1 8 4 . 5 4}$ & 7824. & 1704. & 6120. \\
$\quad \begin{array}{l}\text { Total } \\
\text { reactor }\end{array}$ & $\mathbf{1 9 2 3 . 1 2 0}$ & $\mathbf{4 3 9 . 9 8 4}$ & $\mathbf{1 4 8 3 . 1 3 6}$ & $\mathbf{9 9 3 6 . 0}$ & $\mathbf{2 2 7 3 . 6}$ & $\mathbf{7 6 6 2 . 4}$ \\
\hline
\end{tabular}

The WCLL DCD BOP BB PHTS constitutes two independent primary systems:

- $\quad$ The BZ primary system (BZ PHTS);

- $\quad$ The FW primary system (FW PHTS).

The main components of the WCLL BB PHTS are indicated in the 3D CAD model (see Figure 1). Table 4 reviews the system-relevant data $[2,7,19,20]$. Details of the system architecture can be found in [18].

During normal operations, in pulse time, BZ and FW PHTSs transfer power to the PCS, through two once through steam generators (OTSGs) per system (i.e., four SGs in total). The BZ PHTS power is $1483 \mathrm{MW}$, and the FW PHTS power is $439.8 \mathrm{MW}$. A total of six main coolant pumps (MCPs) are installed to allow the circulation of the primary coolant (four pumps for BZ PHTS and two for FW PHTS). Each PHTS is equipped with a pressurizer (PRZ).

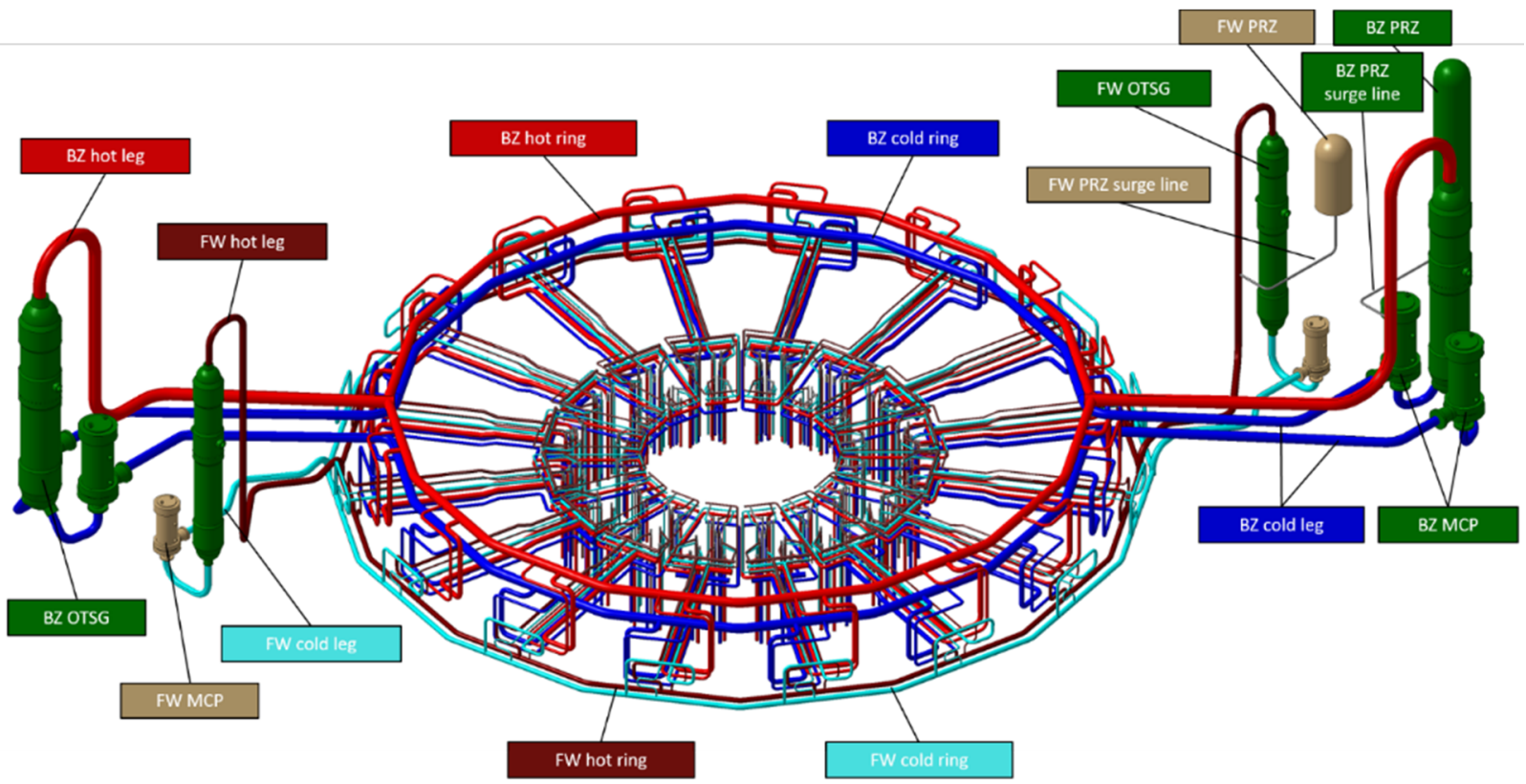

Figure 1. Overview of the DEMO WCLL BB PHTS. 
Table 4. System-relevant parameters.

\begin{tabular}{|c|c|c|}
\hline $\begin{array}{l}\text { WCLL DCD BOP BB PHTS Design and } \\
\text { Operating Parameters }\end{array}$ & BZ & FW \\
\hline \multicolumn{3}{|c|}{ General } \\
\hline Thermal power (MW) & 1483 & 439.8 \\
\hline Operating pressure (MPa) & 15.5 & 15.5 \\
\hline Reactor vessel inlet temperature $\left({ }^{\circ} \mathrm{C}\right)$ & 295 & 295 \\
\hline Reactor vessel outlet temperature $\left({ }^{\circ} \mathrm{C}\right)$ & 328 & 328 \\
\hline Overall volume $\left(\mathrm{m}^{3}\right)$ & $\sim 563$ & $\sim 159$ \\
\hline Overall PHTS piping length $(\mathrm{km})$ & $\sim 3.2$ & $\sim 3.7$ \\
\hline Number of loops & 2 & 2 \\
\hline \multicolumn{3}{|c|}{ Loop data } \\
\hline Piping length (km) & $\sim 1.25$ & $\sim 1.52$ \\
\hline Hot/cold manifolds per loop and size & $\begin{array}{c}8 / 8 \\
\text { DN-150, DN-200, DN-350 }\end{array}$ & $\begin{array}{c}8 / 8 \\
\text { DN-100, DN-125, DN-200 }\end{array}$ \\
\hline Hot/cold legs per loop and size & $\begin{array}{c}1 / 2 \\
\text { DN-850, DN-650 }\end{array}$ & $\begin{array}{c}1 / 1 \\
\text { DN-500, DN-500 }\end{array}$ \\
\hline Hot/cold ring header per loop and size & $\begin{array}{c}1 / 2 \\
\text { DN-650 }\end{array}$ & $\begin{array}{c}1 / 1 \\
\text { DN-350 }\end{array}$ \\
\hline \multicolumn{3}{|c|}{ Pump } \\
\hline Number of pumps per loop & 2 & 1 \\
\hline Type & Centrifugal, vertical single-stage (RSR) & Centrifugal, vertical single-stage (RSR) \\
\hline Effective pump power to coolant (MW) & 3.03 & 1.79 \\
\hline \multicolumn{3}{|c|}{ Pressurizer } \\
\hline Number of units & 1 & 1 \\
\hline Total volume $\left(\mathrm{m}^{3}\right)$ & 101.4 & 32.5 \\
\hline Liquid volume $\left(\mathrm{m}^{3}\right)$ & 44.8 & 16.3 \\
\hline \multicolumn{3}{|c|}{ Heat Exchanger (Steam Generator) } \\
\hline Number of units & 2 & 2 \\
\hline Steam generator power $\left(\mathrm{MW}_{\mathrm{th}} / \mathrm{unit}\right)$ & 742 & 219.9 \\
\hline Type & OTSG & OTSG \\
\hline Heat transfer area (m²/unit) & 4903 & 1423 \\
\hline Feedwater temperature $\left({ }^{\circ} \mathrm{C}\right)$ & 238 & 238 \\
\hline Exit steam pressure (MPa) & 6.4 & 6.4 \\
\hline Steam flow per SG $(\mathrm{kg} / \mathrm{s})$ & 404 & 119.9 \\
\hline Flow rate per SG $(\mathrm{kg} / \mathrm{s})$ & 3831.2 & 1136 \\
\hline
\end{tabular}

\subsection{BZ Once through Steam Generator}

In the BZ Primary System, each OTSG removes $742 \mathrm{MW}_{\text {th }}$ of thermal power, with a mass flow rate of coolant equal to $3831.2 \mathrm{~kg} / \mathrm{s}$. On the secondary side, the water is assumed to be at a pressure of $6.4 \mathrm{MPa}$, and the feedwater coolant inlet temperature is expected to be at $238{ }^{\circ} \mathrm{C}$. The feedwater flow rate is imposed at $404 \mathrm{~kg} / \mathrm{s}$, in order to produce the same amount of superheated steam at $299^{\circ} \mathrm{C}$. It is important to underline that the OTSG is still in a design phase [21,22]. A simplified scheme of a generic OTSG is shown in Figure 2 and the main characteristics are summarized in Table 5.

The selected OTSG is characterized by 7569 tubes, with a length of $12.987 \mathrm{~m}$. 


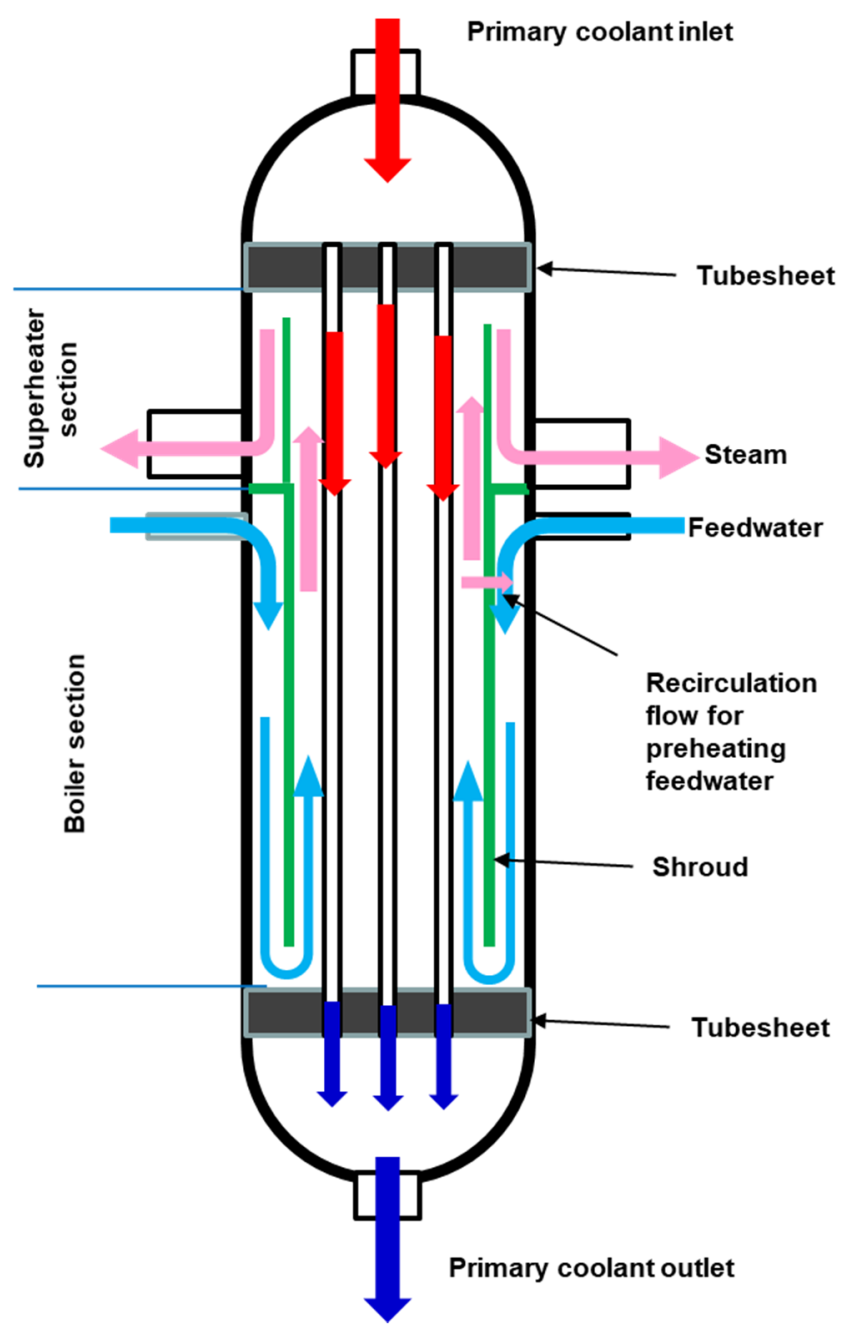

Figure 2. Conceptual scheme for once through steam generator [21].

Table 5. Main features of an OTSG.

\begin{tabular}{ccc}
\hline SG Power & MW $_{\text {th }}$ & 742 \\
\hline Primary side pressure & $\mathrm{MPa}$ & 15.5 \\
\hline Primary side water $\mathbf{T}_{\text {in }}$ & ${ }^{\circ} \mathrm{C}$ & 328 \\
\hline Primary side water $\mathbf{T}_{\text {out }}$ & ${ }^{\circ} \mathrm{C}$ & 295 \\
\hline Secondary side pressure & $\mathrm{MPa}$ & 6.41 \\
\hline Secondary side water $\mathbf{T}_{\text {in }}$ & ${ }^{\circ} \mathrm{C}$ & 238 \\
\hline Secondary side water $\mathbf{T}_{\text {out }}$ & ${ }^{\circ} \mathrm{C}$ & 299 \\
\hline No. of tubes & -- & 7569 \\
\hline Tube OD & $\mathrm{mm}$ & 15.88 \\
\hline Tube thickness & $\mathrm{mm}$ & 0.864 \\
\hline Tube length & $\mathrm{m}$ & 12.987 \\
\hline Tubesheet lattice & -- & Square \\
\hline Tubesheet p/D & -- & 1.28 \\
\hline Heat transfer area & $\mathrm{m}^{2}$ & 4903 \\
\hline V water tubes & $\mathrm{m}^{3}$ & 20 \\
\hline Dext vessel & $\mathrm{m}$ & 2.9 \\
\hline
\end{tabular}




\section{3. $B B$ and PHTS Integration}

The WCLL DEMO 2018 blanket is composed of 16 sectors $\left(22.5^{\circ}\right)$ in the toroidal direction $[4,23]$. Each sector consists of three poloidal segments in the OB (outboard) blanket and two poloidal segments in the IB (inboard) blanket. The geometrical features and the inventory of the WCLL-BB are provided in Table 6.

The inner structure of each segment comprises a stack of about 100 toroidal-radial so-called breeding units (BUs). The BU is a sort of elementary cell repeated along the poloidal direction of each segment. It features the integrated FW-SW complex, the BZ, and the corresponding part of manifolds and BSS.

The coolant feeding pipes deliver cold water to FW and BZ systems, whilst the outlet pipes collect hot water and distribute it to the PHTS.

Considering the FW and $\mathrm{BZ}$ systems, the volume of water is estimated taking into account the BUs (assuming a rough value of 100 for each sector), the manifolds, and the feeding pipes. Furthermore, the velocities in the inlet feeding pipes and distributors were calculated assuming a density of $737.1 \mathrm{~kg} / \mathrm{m}^{3}\left(15.5 \mathrm{MPa}\right.$ and $\left.295^{\circ} \mathrm{C}\right)$, while a density of $657.5 \mathrm{~kg} / \mathrm{m}^{3}\left(15.5 \mathrm{MPa}\right.$ and $\left.328^{\circ} \mathrm{C}\right)$ was taken for the outlet pipes and collectors. The main geometrical data are provided in Table 6.

Table 6. WCLL BB In-Vessel inventory.

\begin{tabular}{|c|c|c|c|c|c|c|c|c|c|}
\hline Description & $\begin{array}{l}\text { Pipe } \\
\text { Size }\end{array}$ & $\begin{array}{l}\text { OD } \\
(\mathrm{mm})\end{array}$ & $\begin{array}{l}\text { Thick. } \\
(\mathrm{mm})\end{array}$ & $\begin{array}{l}\text { MF Total } \\
(\mathrm{kg} / \mathrm{s})\end{array}$ & $\begin{array}{c}\mathrm{v} \\
(\mathrm{m} / \mathrm{s})\end{array}$ & $\begin{array}{c}\mathrm{L} \\
(\mathrm{m})\end{array}$ & $\begin{array}{l}\text { L Tot } \\
\text { (m) }\end{array}$ & $\underset{\left(m^{3}\right)}{V}$ & $\begin{array}{c}\mathrm{H}_{2} \mathrm{O} \text { Mass } \\
\text { Inventory } \\
(\mathrm{kg})\end{array}$ \\
\hline Inlet IB FW distributor & DN-100 & 114.3 & 8.8 & 35.6 & 6.6 & 17.6 & 281.2 & 2.07 & 1522.21 \\
\hline Inlet IB FW LIBS/RIBS & DN-100 & 114.3 & 8.8 & 17.8 & 3.3 & 5.8 & 186.5 & 1.37 & 1009.43 \\
\hline Outlet IB FW LIBS/RIBS & DN-100 & 114.3 & 8.8 & 17.8 & 3.7 & 6.4 & 203.9 & 1.50 & 984.62 \\
\hline Outlet IB FW collector & DN-100 & 114.3 & 8.8 & 35.6 & 7.4 & 17.6 & 281.2 & 2.07 & 1357.82 \\
\hline Inlet IB BZ distributor & DN-200 & 219.1 & 17.5 & 96.4 & 4.9 & 17.5 & 280.3 & 7.46 & 5500.35 \\
\hline Inlet IB BZ LIBS/RIBS & DN-150 & 168.3 & 12.7 & 48.2 & 4.1 & 4.0 & 128.1 & 2.05 & 1513.83 \\
\hline Outlet IB BZ LIBS/RIBS & DN-150 & 168.3 & 12.7 & 48.2 & 4.6 & 4.7 & 149.1 & 2.39 & 1572.12 \\
\hline Outlet IB BZ collector & DN-200 & 219.1 & 17.5 & 96.4 & 5.5 & 17.5 & 279.9 & 7.45 & 4898.97 \\
\hline Inlet OB FW distributor & DN-200 & 219.1 & 17.5 & 106.5 & 5.4 & 11.3 & 180.8 & 4.81 & 3548.13 \\
\hline Inlet OB FW COBS & DN-125 & 139.7 & 11.0 & 35.5 & 4.4 & 7.9 & 126.4 & 1.38 & 1013.89 \\
\hline Inlet OB FW LOBS/ROBS & DN-125 & 139.7 & 11.0 & 35.5 & 4.4 & 9.2 & 293.9 & 3.20 & 2357.06 \\
\hline Outlet OB FW COBS & DN-125 & 139.7 & 11.0 & 35.5 & 5.0 & 8.3 & 133.1 & 1.45 & 952.47 \\
\hline $\begin{array}{l}\text { Outlet OB FW } \\
\text { LOBS/ROBS }\end{array}$ & DN-125 & 139.7 & 11.0 & 35.5 & 5.0 & 9.4 & 301.6 & 3.28 & 2157.42 \\
\hline Outlet OB FW collector & DN-200 & 219.1 & 17.5 & 106.5 & 6.1 & 11.5 & 183.3 & 4.88 & 3208.51 \\
\hline Inlet OB BZ distributor & DN-350 & 355.6 & 28.0 & 382.4 & 7.4 & 10.6 & 170.3 & 12.00 & 8847.80 \\
\hline Inlet OB BZ COBS & DN-200 & 219.1 & 17.5 & 127.5 & 6.5 & 7.0 & 111.5 & 2.97 & 2187.86 \\
\hline Inlet OB BZ LOBS/ROBS & DN-200 & 219.1 & 17.5 & 127.5 & 6.5 & 7.4 & 236.1 & 6.29 & 4633.48 \\
\hline Outlet OB BZ COBS & DN-200 & 219.1 & 17.5 & 127.5 & 7.3 & 7.7 & 122.7 & 3.27 & 2147.62 \\
\hline $\begin{array}{l}\text { Outlet OB BZ } \\
\text { LOBS/ROBS }\end{array}$ & DN-200 & 219.1 & 17.5 & 127.5 & 7.3 & 8.4 & 267.9 & 7.13 & 4688.31 \\
\hline Outlet OB BZ collector & DN-350 & 355.6 & 28.0 & 382.4 & 8.2 & 11.0 & 176.3 & 12.43 & 8172.15 \\
\hline Total & & & & & & & 4094.1 & 89.44 & $62,274.06$ \\
\hline
\end{tabular}

\section{Postulated Accidental Scenario}

In this section, the specifications of the accident-such as the event sequence and the main objectives-are reported and described in Tables 7-10. 
Table 7. Accidental scenario general specifications.

\begin{tabular}{ll}
\hline Parameter & Specification \\
\hline \multirow{2}{*}{ Name of event } & $\begin{array}{l}\text { LBO3 out-vessel loss of coolant from the breeder primary loop due to large rupture of tubes in a } \\
\text { primary HX in WCLL concept }\end{array}$ \\
\cline { 2 - 2 } Category & Accident \\
\cline { 2 - 2 } Objectives & $\begin{array}{l}\text { Show that accidental overpressure in the secondary loop of PHTS will be safely accommodated. } \\
\text { Show that post-accident cooling of the decay heat removal system of the VV is sufficient to remove } \\
\text { decay heat during the } 32 \mathrm{~h} \text { of the offsite loss of power. } \\
\text { Show that radioactive releases, if any, are adequately confined. }\end{array}$ \\
\cline { 2 - 2 } Scope of analysis & $\begin{array}{l}\text { Integrated breeder blanket PHTS thermohydraulic analysis. } \\
\text { VV, VVPSS(W) pressure transient analysis if melting occurs due to mitigated plasma disruption. } \\
\text { Analysis of ACPs and tritium transport in the containment volumes as a consequence of the plasma } \\
\text { disruption, if melting occurs. }\end{array}$ \\
\cline { 2 - 2 } Acceptance criteria & $\begin{array}{l}\text { Maximum Eurofer temperature }<550{ }^{\circ} \mathrm{C} \\
\text { Confinement integrity: BB module safety assessment pressure }<18 \mathrm{MPa} \\
\text { Confinement integrity: VV safety assessment pressure }<200 \mathrm{kPa}\end{array}$ \\
\hline
\end{tabular}

Table 8. Accidental scenario main events sequence.

\begin{tabular}{|c|c|}
\hline Parameter & Specification \\
\hline Definition of initiating event & $\begin{array}{l}\text { Break in the primary cooling loop side (break size } 0.0028 \mathrm{~m}^{2} \text {, corresponding to } \\
\text { the rupture of } 9 \text { tubes of the primary side) inside the HX toward the secondary } \\
\text { side. }\end{array}$ \\
\hline Possible transient sequence & $\begin{array}{l}\text { Fusion power is terminated by loss of pressure ( }-20 \% \text { of operating pressure) } \\
\text { in the BB cooling loop inside the HX. The initiating event is followed by a fast } \\
\text { plasma shutdown (FPS) actuated } 3 \mathbf{s} \text { from the low signal, which leads to a } \\
\text { mitigated plasma disruption for } 5 \mathrm{~ms} \text {. } \\
\text { The disruption could cause failure of the FW cooling pipes in a BB module if } \\
\text { temperature melting is reached in FW Eurofer. In such a case, the break flow area } \\
\text { to be considered is reported in [SDL19], chapter } 2.1 \text {. } \\
\text { The VV decay heat removal cooling loops will cool down the in-vessel components } \\
\text { post accident. } \\
\text { Ingress of coolant and radioactive inventories (tritium, dust, and suspended } \\
\text { products) will be mobilized. } \\
\text { The rupture discs toward the VVPSS(W) open upon reaching the set VV pressure } \\
\text { point. } \\
\text { Mobilized radioactivity is transported into the VVPSS(W). } \\
\text { After the coolant inventory is lost, the FW/breeder blanket modules will be cooled } \\
\text { by steam convection and thermal conduction/radiation to the VV. } \\
\text { The DV components are accounted for in this analysis as heat structures at the } \\
\text { initial temperature and without cooling during the transient. }\end{array}$ \\
\hline \multirow{2}{*}{$\begin{array}{l}\text { Aggravating failures } \\
\text { Loss of power }\end{array}$} & None. \\
\hline & A loss of offsite power occurs at the same time of the plasma disruption. \\
\hline
\end{tabular}

Table 9. Accidental scenario system assumptions.

\begin{tabular}{ll}
\hline Parameter & Specification \\
\hline Process system assumptions & VV decay heat removal (DHR) will remove the decay heat. The temperature of the \\
VV is maintained at $40{ }^{\circ} \mathrm{C}$ by DHR. \\
\cline { 2 - 2 } Safety systems assumptions & $\begin{array}{l}\text { VV pressure limit is } 0.2 \mathrm{MPa} . \\
\text { VVPSS }(\mathrm{W}) \text { rupture discs open upon reaching the VV pressure set point. }\end{array}$ \\
\cline { 2 - 2 } Source term & $\begin{array}{l}\text { Tritium, dust in the VV, ACP products in the PHTS, tritium and activated products } \\
\text { in the breeder materials and/or purge gas. }\end{array}$ \\
\hline
\end{tabular}


Table 10. Expected results from the analysis of the accidental scenario.

\begin{tabular}{|c|c|}
\hline Parameter & Specification \\
\hline General & $\begin{array}{l}\text { The output locations, parameters, and time trace should show the results of safety } \\
\text { analyses to support objectives and purposes. } \\
\text { The time span should cover until the transients are stabilized. }\end{array}$ \\
\hline FW temperature & Transient curve for FW and BB module temperature of the failed loop. \\
\hline Confinement response & $\begin{array}{l}\text { Pressures and atmosphere temperature in BB cooling loop, HX. } \\
\text { Pressures and atmosphere temperature in VV and VVPSS(W) only in case of FW } \\
\text { Eurofer structure melting. }\end{array}$ \\
\hline Cooling system conditions & $\begin{array}{l}\text { Water break flow versus time in } \mathrm{HX} \text { and in VV and VVPSS(W) only in case of FW } \\
\text { Eurofer structure melting. } \\
\text { Water inventory inside the affected FW/breeder blanket cooling system. }\end{array}$ \\
\hline Radioactive transport & $\begin{array}{l}\text { Transient curves for tritium, dust, and sputtering concentration (airborne, } \\
\text { deposited) in VVPSS(W) if FW structure melts. } \\
\text { Bookkeeping of mobilized tritium, dust, and sputtering products if FW structure } \\
\text { melts. }\end{array}$ \\
\hline
\end{tabular}

\section{Nodalization of the WCLL-PHTS}

Figure 3 shows the whole nodalization of the BZ loop. Since the loop is symmetrical with respect to the two OTSGs, only half of the loop is represented, without losing consistency. All the geometrical characteristics of the components of the nodalization were retrieved from the references presented above and summarized in the previous sections of this document. A list of all the main characteristics can be found in Tables 7 and 8 .

The whole nodalization can be roughly divided into two sections: the main one, more complex, which is the nodalization of the BZ OTSG, and the simpler one, which is the nodalization of the BB volumes; the two regions are highlighted in Figure 3, whilst a focus on the BZ OTSG is shown in Figure 4. The cold and hot rings provide a connection between the two regions. The pressurizer is directly connected to the hot ring.

The OTSG is partitioned in the primary and secondary side. Each side is divided into several control volumes (CVH in MELCOR), which correspond to the hemispherical top and bottom, as well as to the sections created by the support plates. The division into different sections is required to achieve a temperature gradient as close as possible to the actual one. All the control volumes are connected by flow paths (FL). CVH 10 and 11 (see Figure 4) are dummy volumes used only to impose the BCs to the secondary side at normal operations. The CHV and FL geometrical characteristics are summarized in Tables 11 and 12, respectively.

In normal conditions, the primary and secondary side are connected only by heat structures (HSs), which allows heat transfer between the volumes but do not permit any passage of fluids. Between the primary and secondary side, there are a total of 17 equal heat structures. Each HS has a cylindrical geometry divided into four nodes with a total thickness of $0.8 \mathrm{~mm}$ and a height of $0.7825 \mathrm{~m}$, which corresponds to the height of the connected volumes. The multiplicity of the HS is equal to 7569 , which means that the HS is equivalent to 7569 heat structures of the same type, for a total surface area of $4795 \mathrm{~m}^{2}$. All HSs are made of stainless steel, and a convective condition is imposed on both sides of the HS.

The thermal power of the OTSG is simulated by means of two heat structures connected with the inboard and outboard sections of the BB regions. These two HSs provide $592 \mathrm{MW}$ of thermal power to the outboard section (CVH 15) and $149 \mathrm{MW}$ to the inboard section (CVH 14).

The accident is simulated by activating dummy flow paths which connect one volume of the primary side with the corresponding volume of the secondary side. The section area of this FL is equal to the rupture area $\left(0.00312 \mathrm{~m}^{2}\right.$ for nine tubes on the OTSG primary side). 
These FLs are located at different heights to allow sensitivity analysis on the location of the rupture.

Table 11. CVH number and characteristics.

\begin{tabular}{|c|c|c|c|c|}
\hline $\begin{array}{c}\text { Nodalization } \\
\text { CVH }\end{array}$ & $\begin{array}{c}\text { Volume Water } \\
\left(\mathrm{m}^{3}\right)\end{array}$ & $\begin{array}{c}\text { Height/Length } \\
\text { (m) }\end{array}$ & $\begin{array}{c}\text { Section } \\
\left(\mathrm{m}^{2}\right)\end{array}$ & Description \\
\hline \multicolumn{5}{|l|}{ Primary side } \\
\hline 1 & 3.22 & 1.15 & 4.18 & Top hemisphere \\
\hline 2 & 0.72 & 0.61 & 1.18 & Top tubesheet \\
\hline $31-46$ & 15.36 & 0.7825 & 1.18 & Shroud tubes primary \\
\hline 4 & 0.72 & 0.61 & 1.18 & Bottom tubesheet \\
\hline 5 & 3.22 & 1.15 & 4.18 & Bottom hemisphere \\
\hline \multicolumn{5}{|l|}{ Secondary side } \\
\hline 6 & 12.65 & 7.63 & 1.66 & Shell boiler \\
\hline $71-86$ & 34.09 & 12.70 & 2.68 & Shroud secondary \\
\hline 8 & 1.81 & 0.30 & 6.03 & Steam chamber \\
\hline 9 & 8.42 & 5.08 & 1.66 & Shell SH \\
\hline \multicolumn{5}{|l|}{ Rings and BB } \\
\hline 12 & 36.04 & 146.5 & 0.246 & Hot ring \\
\hline 13 & 36.04 & 146.5 & 0.246 & Cold ring \\
\hline 16 & 7.73 & 17.9 & 0.027 & $\begin{array}{l}\text { Cold ring distributors } \\
\text { IB }\end{array}$ \\
\hline 18 & 14.67 & 13.1 & 0.07 & $\begin{array}{l}\text { Cold ring distributors } \\
\text { OB }\end{array}$ \\
\hline 17 & 7.99 & 18.5 & 0.027 & Hot ring collectors IB \\
\hline 19 & 15.9 & 14.2 & 0.07 & Hot ring collectors $\mathrm{OB}$ \\
\hline 14 & 73.7 & 14.7 & - & BB inboard \\
\hline 15 & 121.616 & 12.3 & - & BB outboard \\
\hline
\end{tabular}

Table 12. FL number and characteristics.

\begin{tabular}{|c|c|c|c|c|c|c|c|}
\hline $\begin{array}{c}\text { Nodalization } \\
\text { FL }\end{array}$ & $\begin{array}{l}\text { From } \\
\text { CVH }\end{array}$ & $\begin{array}{c}\text { To } \\
\text { CVH }\end{array}$ & $\begin{array}{c}\text { From Height } \\
\text { (m) }\end{array}$ & $\begin{array}{c}\text { To Height } \\
\text { (m) }\end{array}$ & $\begin{array}{l}\text { Section } \\
\left(\mathrm{m}^{2}\right)\end{array}$ & $\begin{array}{c}\text { Hydraulic } \\
\text { Diameter } \\
(\mathrm{m})\end{array}$ & $\begin{array}{l}\text { Length } \\
\text { (m) }\end{array}$ \\
\hline \multicolumn{8}{|l|}{ Primary side } \\
\hline FL00100 & 12 & 1 & 4.25 & 16.5272 & 0.4117 & 0.724 & 45 \\
\hline FL00200 & 1 & 2 & 15.3732 & 15.3732 & 1.1818 & 1.2267 & 0 \\
\hline FL00300 & 2 & 31 & 14.7636 & 14.7636 & 1.1818 & 1.2267 & 0 \\
\hline FL03100 TO FL04600 & $(31)$ & $(46)$ & 13.9811 & 13.9491 & 1.1818 & 0.0141 & 0.032 \\
\hline FL00400 & 46 & 4 & 1.7636 & 1.7636 & 1.1818 & 1.2267 & 0 \\
\hline FL00500 & 4 & 5 & 1.154 & 1.154 & 1.1818 & 1.2267 & 0 \\
\hline \multicolumn{8}{|l|}{ Secondary side } \\
\hline FL00600 & 10 & 6 & 9 & 9 & 0.198639 & 0.0889 & 0 \\
\hline FL07100 TO FL08600 & $(71)$ & $(86)$ & 13.9491 & 13.9811 & 0.89466 & 0.012636 & 0.032 \\
\hline FL00700 & 6 & 71 & 2.2 & 2.2 & 4.330349 & 0.84579 & 0 \\
\hline FL00800 & 86 & 8 & 14.4636 & 14.4636 & 2.6846 & 0.0279 & 0 \\
\hline
\end{tabular}


Table 12. Cont.

\begin{tabular}{|c|c|c|c|c|c|c|c|}
\hline $\begin{array}{c}\text { Nodalization } \\
\text { FL }\end{array}$ & $\begin{array}{l}\text { From } \\
\text { CVH }\end{array}$ & $\begin{array}{c}\text { To } \\
\text { CVH }\end{array}$ & $\begin{array}{l}\text { From Height } \\
\text { (m) }\end{array}$ & $\begin{array}{l}\text { To Height } \\
\text { (m) }\end{array}$ & $\begin{array}{l}\text { Section } \\
\left(\mathrm{m}^{2}\right)\end{array}$ & $\begin{array}{l}\text { Hydraulic } \\
\text { Diameter } \\
\text { (m) }\end{array}$ & $\begin{array}{c}\text { Length } \\
\text { (m) }\end{array}$ \\
\hline \multicolumn{8}{|l|}{ Rings and BB } \\
\hline FL01200 & 5 & 13 & 0 & 2 & 0.246 & 0.56 & 23 \\
\hline FL01300 & 13 & 18 & 1.724 & 1.724 & 0.62 & 0.3 & 10.6 \\
\hline FL01400 & 18 & 15 & -7.746 & -7.746 & 0.564 & 0.1841 & 10.6 \\
\hline FL01500 & 15 & 19 & -7.746 & -7.746 & 0.564 & 0.1841 & 10.6 \\
\hline FL01600 & 19 & 12 & 3.784 & 3.784 & 0.62 & 0.3 & 10.6 \\
\hline FL01700 & 13 & 16 & 1.724 & 1.724 & 0.156 & 0.184 & 17.5 \\
\hline FL01800 & 16 & 14 & -4.446 & -4.446 & 0.255 & 0.1429 & 4 \\
\hline FL01900 & 14 & 17 & -4.446 & -4.446 & 0.255 & 0.1429 & 4 \\
\hline FL02000 & 17 & 12 & 3.784 & 3.784 & 0.156 & 0.184 & 17.5 \\
\hline \multicolumn{8}{|l|}{ Accident } \\
\hline FL10101 & 33 & 84 & 12.7 & 12.7 & 0.0028 & 0.0141 & 0 \\
\hline FL10102 & 39 & 78 & 7.9 & 7.9 & 0.0028 & 0.0141 & 0 \\
\hline FL10103 & 45 & 72 & 2.2 & 2.2 & 0.0028 & 0.0141 & 0 \\
\hline
\end{tabular}



Figure 3. MELCOR nodalization of PHTS loop. 


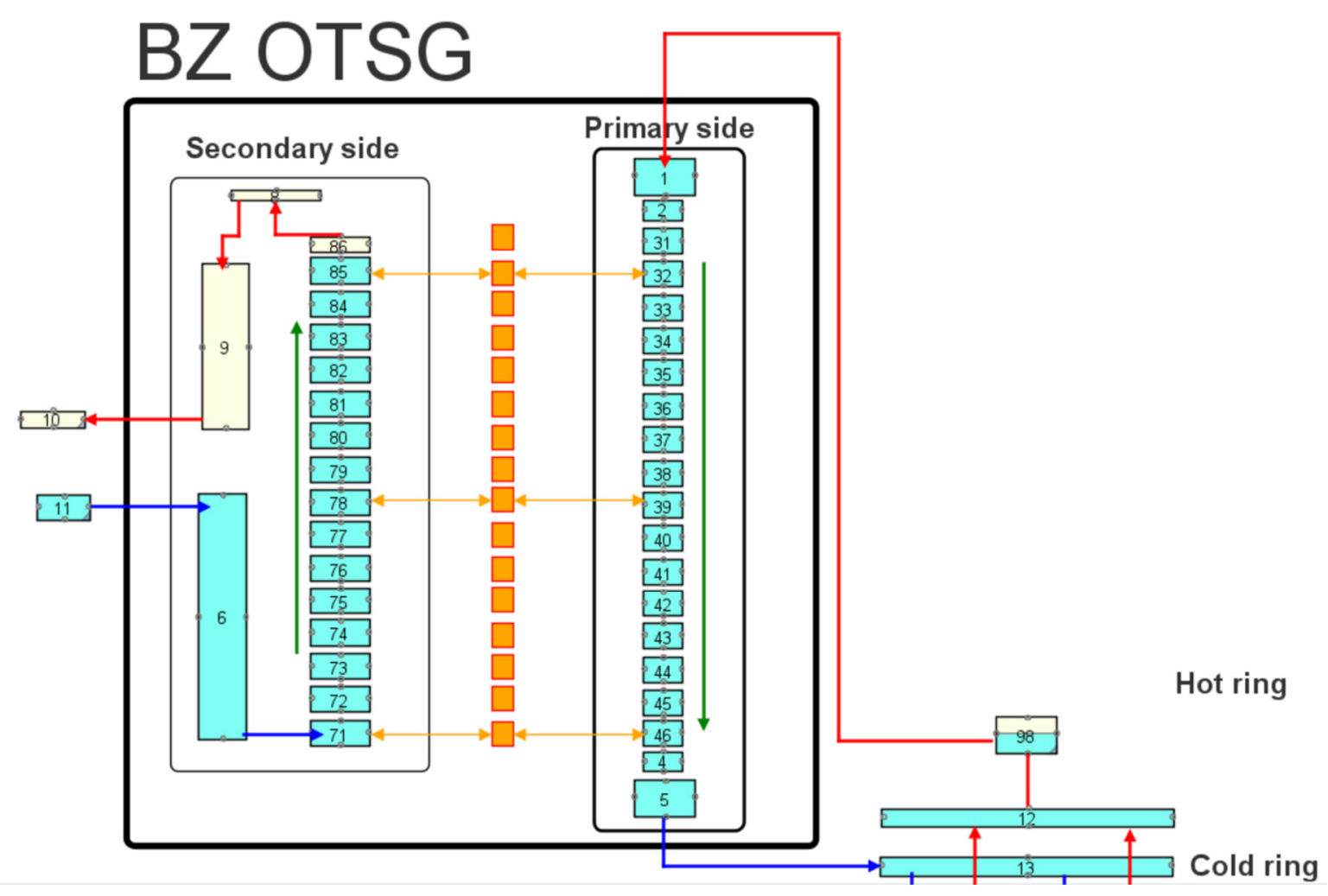

Figure 4. Detail of BZ OTSG nodalization.

\subsection{Boundary Conditions}

In order to impose the required primary coolant mass flow rate of $3831.2 \mathrm{~kg} / \mathrm{s}$, a fluid velocity was imposed at FL12, since MELCOR does not allow to impose directly the mass flowrate. Furthermore, only for the initial steady condition, before the onset of the accident, the temperature on the bottom of the OTSG (CVH 5) was imposed to be $295{ }^{\circ} \mathrm{C}$ and the pressure was set at $15.5 \mathrm{MPa}$.

As mentioned in the previous section, two dummy CVHs (10 and 11) were used to impose the BCs at the secondary side. A pressure of $6.4 \mathrm{MPa}$ and a feedwater coolant inlet temperature of $238{ }^{\circ} \mathrm{C}$ were imposed. The feedwater flow rate is kept at $404 \mathrm{~kg} / \mathrm{s}$ by means of imposing an equivalent constant velocity $\mathrm{FL}$, in order to produce the same amount of superheated steam at $299^{\circ} \mathrm{C}$.

The velocity (mass flow rate) imposed at FL12 was set to 0.0 at the FPS since the pumps were shut down due to the loss of offsite power. Furthermore, at the FPS, the FLs connecting the secondary side of the OTSG to the secondary loop are closed (thus acting as isolation valves), also interrupting the feed water flow in the secondary side. At the current stage, the design of the secondary loop is not completed.

\subsection{Decay Heat}

The decay heat was imposed using volumetric heat generation from heat structures connected with the outboard and inboard $\mathrm{CVH}$. The total values and time trends, calculated using the most up-to-date volumetric nuclear heating data given in [24], are reported in Table 13. 
Table 13. Decay heat densities $\left(\mathrm{MW} / \mathrm{m}^{3}\right)$ integrated into the WCLL full reactor [24].

\begin{tabular}{|c|c|c|c|c|c|c|}
\hline Entire Reactor & & & & & & \\
\hline \multirow[t]{2}{*}{ Name of Zone } & $\begin{array}{l}\text { Nuclear } \\
\text { Heating }\end{array}$ & \multicolumn{5}{|c|}{ Cooling Time } \\
\hline & $\mathrm{MW} / \mathrm{m}^{3}$ & \multicolumn{5}{|c|}{$\mathrm{MW} / \mathrm{m}^{3}$} \\
\hline First wall (FW) & & $0 \mathrm{~s}$ & $1 \mathrm{~s}$ & $1 \mathrm{~h}$ & 1 day & 1 week \\
\hline $\mathbf{W}$ & $2.18 \mathrm{E}+01$ & $4.95 \mathrm{E}-01$ & 4.93E-01 & 4.63E-01 & $2.27 \mathrm{E}-01$ & $5.66 \mathrm{E}-03$ \\
\hline Eurofer & $7.14 \mathrm{E}+00$ & $1.76 \mathrm{E}-01$ & $1.76 \mathrm{E}-01$ & $1.01 \mathrm{E}-01$ & $1.34 \mathrm{E}-02$ & $6.91 \mathrm{E}-03$ \\
\hline \multicolumn{7}{|l|}{$\begin{array}{c}\text { Breeder } \\
\text { module (BM) }\end{array}$} \\
\hline $\begin{array}{l}\text { BM caps and } \\
\text { lateral walls }\end{array}$ & $1.81 \mathrm{E}+00$ & $1.08 \mathrm{E}-02$ & $1.08 \mathrm{E}-02$ & 7.32E-03 & $8.82 \mathrm{E}-04$ & 2.57E-04 \\
\hline $\begin{array}{l}\text { BM material } \\
\text { mixture }\end{array}$ & $1.17 \mathrm{E}+00$ & $1.23 \mathrm{E}-02$ & $9.35 \mathrm{E}-03$ & $3.60 \mathrm{E}-03$ & $1.07 \mathrm{E}-03$ & $9.01 \mathrm{E}-04$ \\
\hline BM backwall & $1.06 \mathrm{E}-01$ & $1.50 \mathrm{E}-03$ & $1.50 \mathrm{E}-03$ & 1.02E-03 & $1.20 \mathrm{E}-04$ & 4.24E-05 \\
\hline $\begin{array}{l}\text { BM back sup- } \\
\text { port/manifold }\end{array}$ & $5.64 \mathrm{E}-02$ & $4.31 \mathrm{E}-04$ & $4.28 \mathrm{E}-04$ & $2.90 \mathrm{E}-04$ & $3.45 \mathrm{E}-05$ & $1.32 \mathrm{E}-05$ \\
\hline Sum $\left(M W / m^{3}\right)$ & $1.65 \mathrm{E}+03$ & $2.21 \mathrm{E}+01$ & $1.91 \mathrm{E}+01$ & $9.68 \mathrm{E}+00$ & $2.26 \mathrm{E}+00$ & $1.25 \mathrm{E}+00$ \\
\hline
\end{tabular}

However, it is important to note that the values reported in [24] did refer to a different configuration of the WCLL, namely, the one which was composed of modules and, therefore, had a different material ratio; in this work, the total nuclear heating was recalculated scaling the values with an estimation of the total volume obtained from the most recent configuration of the inboard and outboard segments, and this may represent a source of error. Furthermore, it is difficult to estimate the role of the FW in cooling the decay heat of the breeding unit under this particular scenario, since-as shown in the results-the FW loop is not damaged by the plasma disruption, and it can be assumed still functional. As a first approach in this work, only the decay nuclear heating relative to the BM back wall and the manifolds is assumed to have an effect on the damaged BZ cooling loops.

\section{Numerical Analyses}

In the simulation, the system was initially left to run for $1000 \mathrm{~s}$, to reach a stable steady state in operational conditions, and then the FL connecting the volumes involved in the rupture was opened. Three seconds after the low-pressure signal, i.e., when the pressure in the loop fell below $12.4 \mathrm{MPa}$, the FPS was activated; plasma disruption occurred, the pumps were stopped, and the secondary loop was isolated.

In total, three different cases were run, at three different rupture locations (top, middle, and bottom). Table 14 summarizes the different cases.

Table 14. Summary of simulation parameters.

\begin{tabular}{ccccc}
\hline & Rupture Location & Number of Pipes & Rupture Size $\left.\mathbf{( m}^{\mathbf{2}}\right)$ & FL Involved \\
\hline Case 1 & Top OTSG & 9 & 0.0028 & FL10101 \\
\hline Case 2 & Middle OTSG & 9 & 0.0028 & FL10102 \\
\hline Case 3 & Bottom OTSG & 9 & 0.0028 & FL10103 \\
\hline
\end{tabular}

The event sequence of the accident is reported in Table 15. 
Table 15. Event sequence.

\begin{tabular}{ccc}
\hline Event & & Time (s) \\
\hline Steady state & & $0-1000$ \\
\hline \multirow{3}{*}{ Low-pressure signal } & Case 1 & 1016.5 \\
\cline { 2 - 3 } & Case 2 & 1008.5 \\
\cline { 2 - 3 } & Case 3 & 1007.5 \\
\hline FPS & Case 1 & 1019.5 \\
\hline & Case 2 & 1011.5 \\
\hline End of the simulation & Case 3 & 1010.5 \\
\hline
\end{tabular}

\subsection{Pressure Evolution}

Figures 5 and 6 show the pressure trend after the rupture, at different time scales. The pressure started decreasing and then showed a sharp peak when the low-pressure signal was reached. This was due to the rapid shutdown of the pump and the isolation of the loop. The same behavior was seen in all the cases, but it is worth noting that, for Case 1, the pressure drop was slower and the peak remained significantly lower than the other two cases. This was due to the different rupture conditions; in Case 1, the primary side discharged in a region of the secondary, which was filled with superheated vapor, whereas, in Cases 2 and 3, it was discharged in regions containing liquid water. Figure 7 shows the time trend of the vapor quality calculated in CVH 85 for Case 1.

Figures 8 and 9 show the pressure trend at the rupture locations of both the primary and the secondary side. In the secondary side of the OTSG, no pressure peaks were predicted, and the pressure increased to an equilibrium value by around $100 \mathrm{~s}$ in all the cases. Then, $200 \mathrm{~s}$ after the rupture, a steady state was reached, with the pressure lying between 12 and $13 \mathrm{MPa}$.

All pressures remained well below the threshold of $18 \mathrm{MPa}$, with the pressure peak for Cases 2 and 3 having a value of about $15 \mathrm{MPa}$, and that for Case 1 having a value of about $12.5 \mathrm{MPa}$.

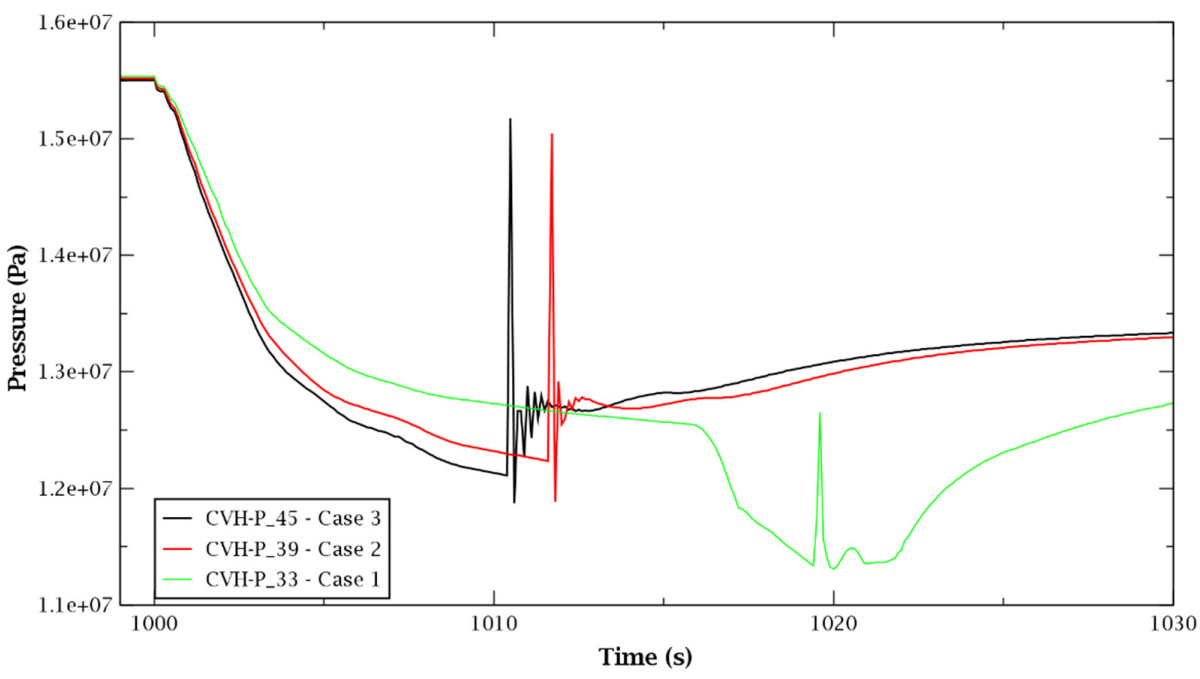

Figure 5. Pressure trend after the rupture: primary side, 1000-1030 s. 


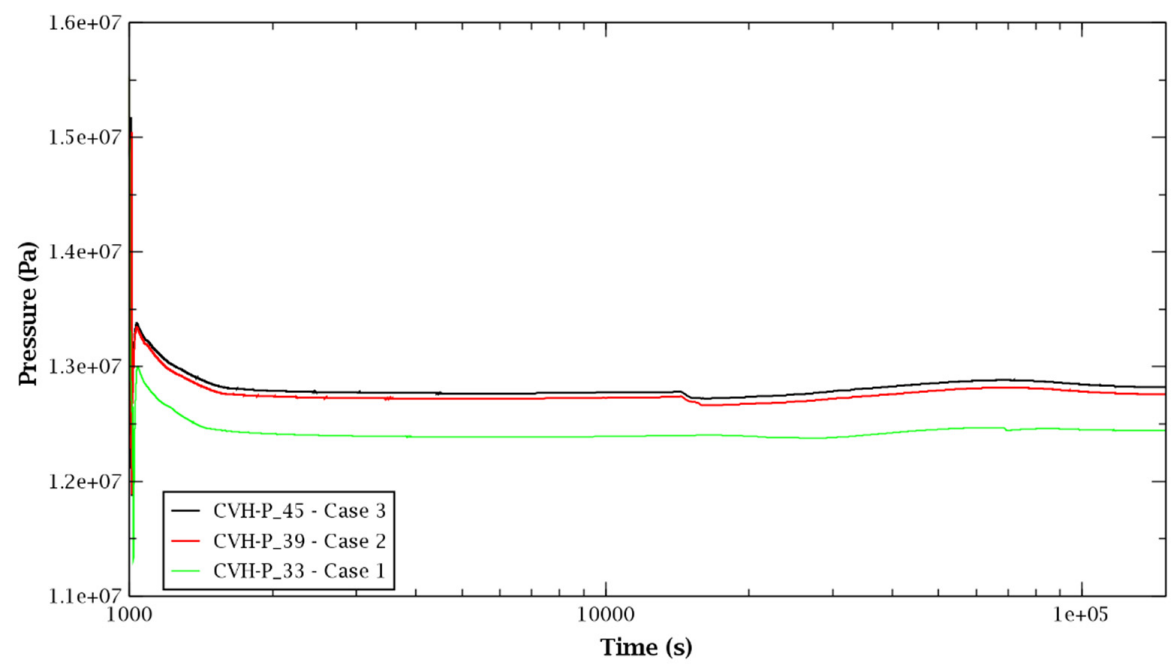

Figure 6. Pressure trend after the rupture: primary side.

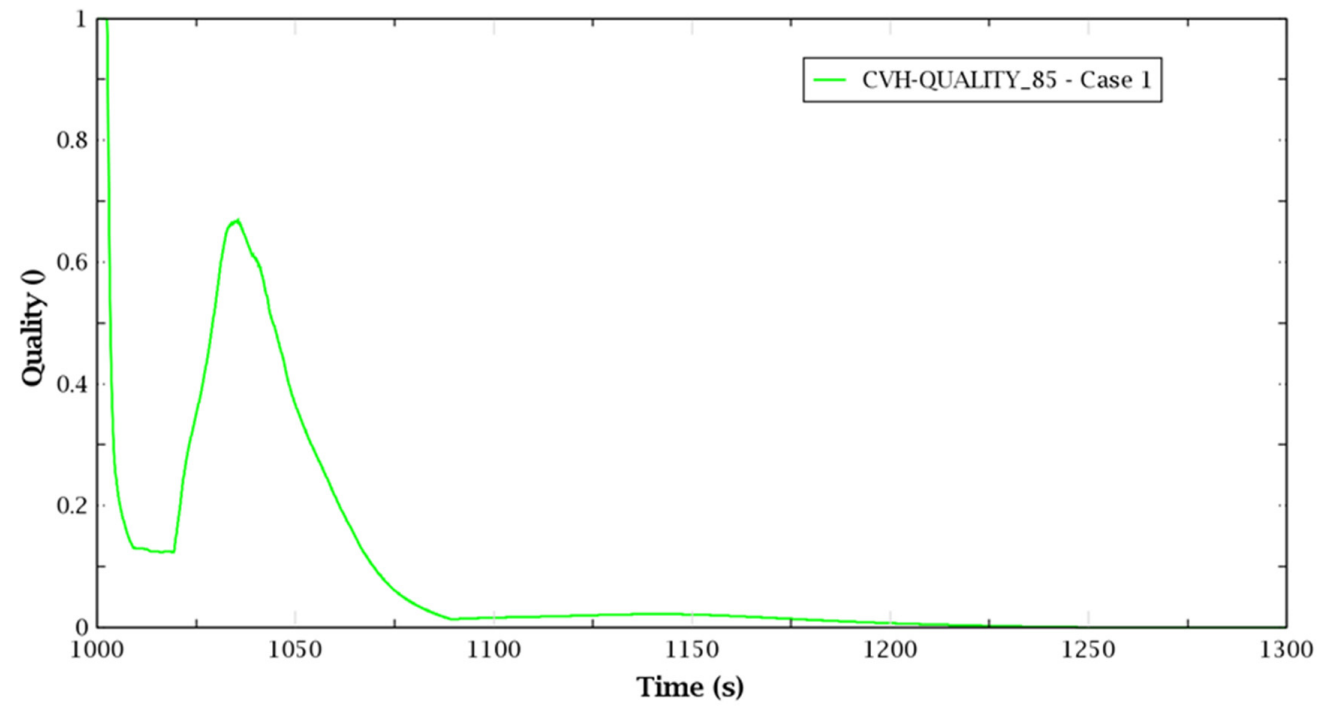

Figure 7. Vapor quality in volume 85 for Case 1.

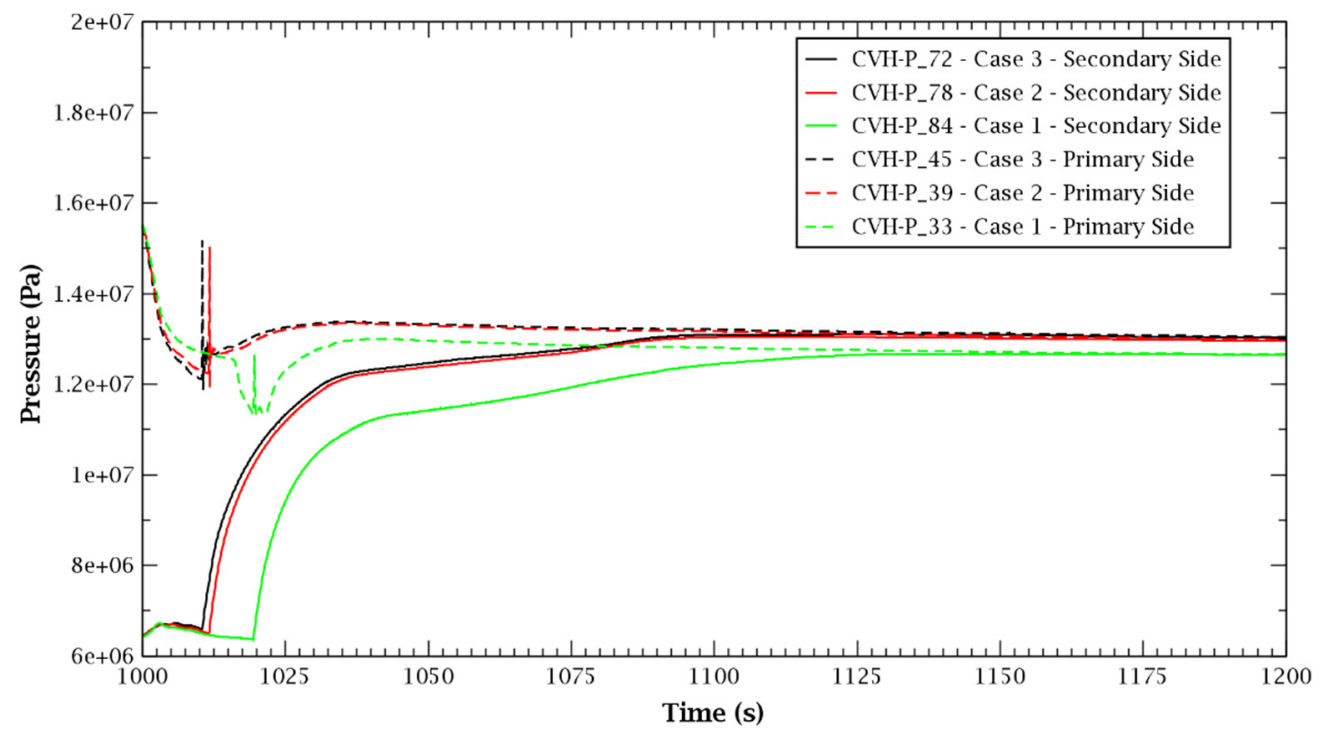

Figure 8. Pressure trend after the rupture: primary and secondary sides, 1000-1200 s. 


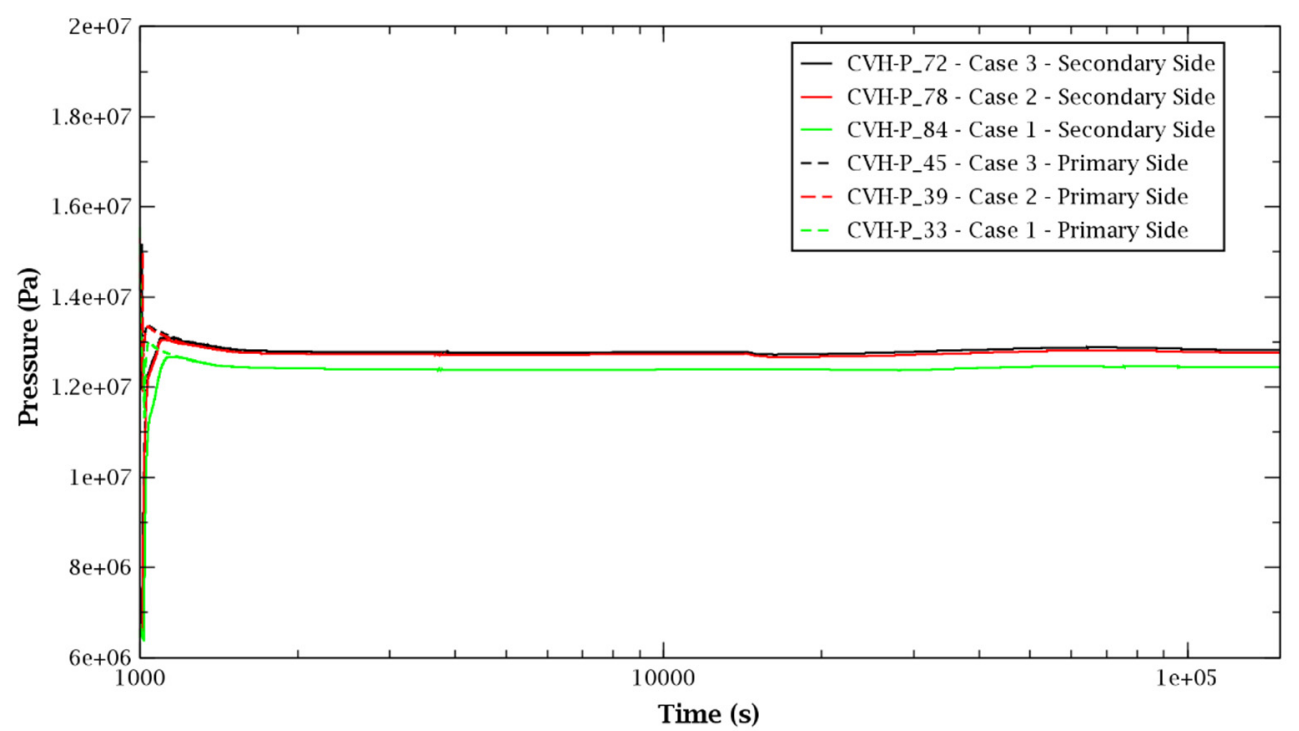

Figure 9. Pressure trend after the rupture: primary and secondary sides.

\subsection{Temperature Evolution in the $B B$}

Figures 10-12 show the time evolution of the temperature at the inlets and outlets of the $\mathrm{BB}$, for the whole transient up to $36 \mathrm{~h}$. Because of the effect of the decay heat, the temperatures did not reach a steady state, but tended to increase. The faster temperature increase after $10^{4} \mathrm{~s}$ was due to the onset of weak natural circulation in the loop, with the water flow even changing direction several times in Cases 2 and 3, as shown in Figure 13. However, the increase could be considered slow throughout the whole transient, and all temperatures remained well below acceptable values.

As mentioned above, the difference between Case 1 and Cases 2 and 3 was due to a different height of the rupture in the primary side of OTSG for the three cases, with a jump of around $5 \mathrm{~m}$ between each case. The transient for Case 1 showed a different behavior from the very beginning, because, in this case, the primary discharged, through the rupture, into a region of the secondary which was filled with superheated vapor and not liquid water, as in Cases 2 and 3. This early difference consequently led to a radically different transient of the pressure and general behavior of the loop, compared with the other two cases.

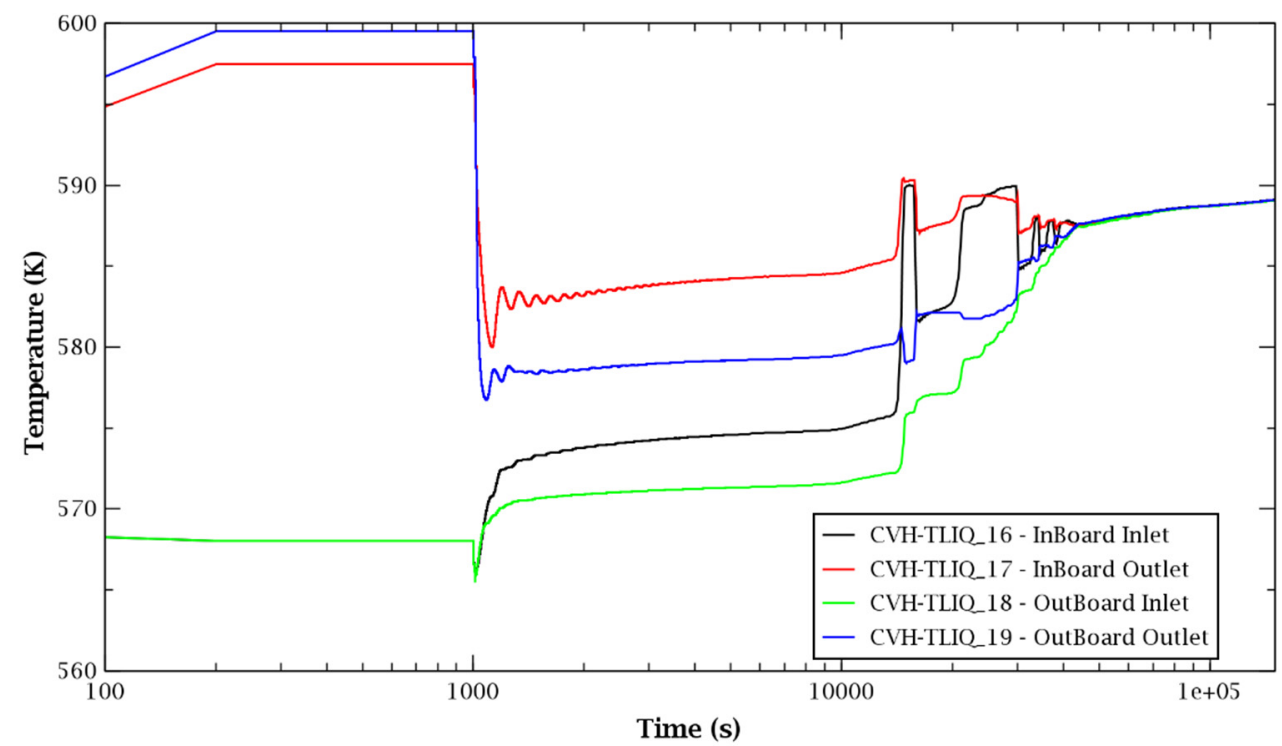

Figure 10. Temperature evolution in the BB: Case 3. 


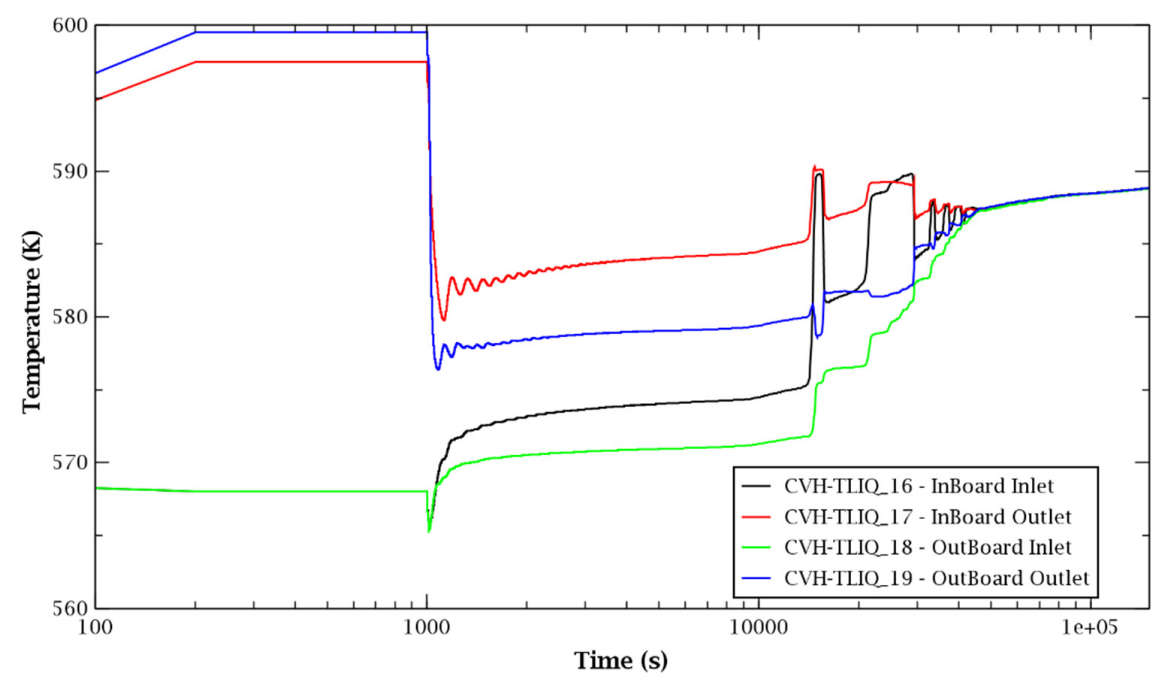

Figure 11. Temperature evolution in the BB: Case 2.

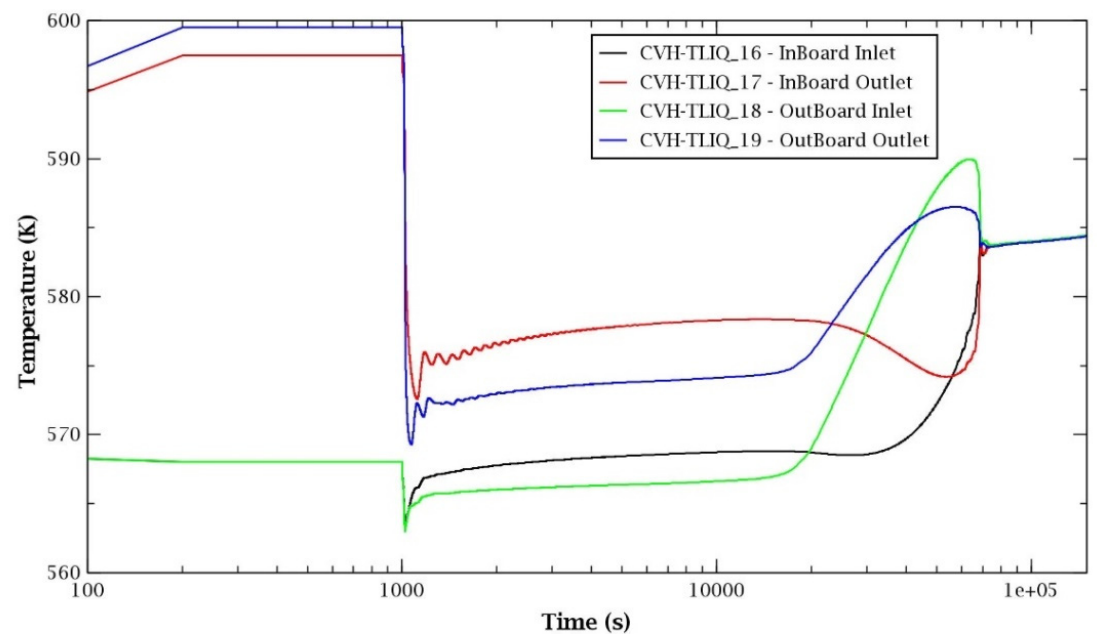

Figure 12. Temperature evolution in the BB: Case 1.

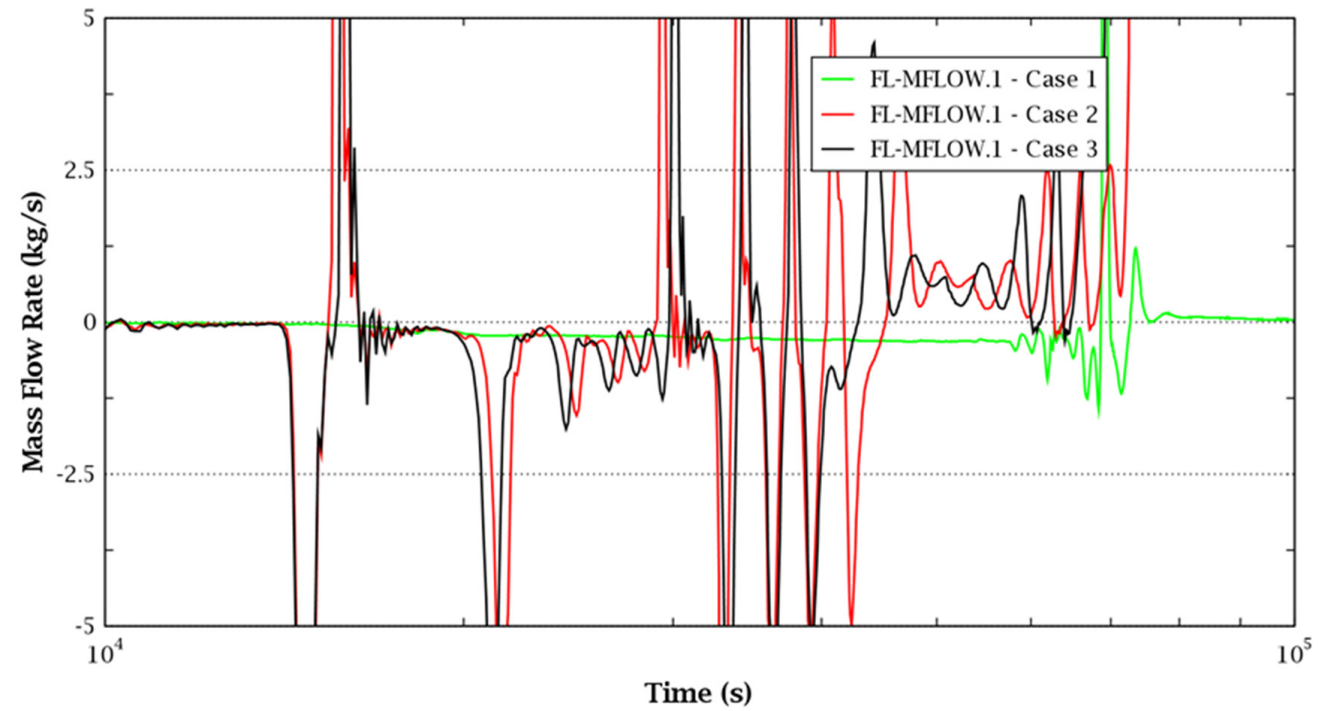

Figure 13. Water mass flow rate in the loop: $10^{4}-10^{5} \mathrm{~s}$. 


\section{Conclusions}

This work presented a thermohydraulic analysis of a postulated accident involving the rupture of a breeder primary loop inside an HX (once through steam generator). After the detection of the loss of pressure inside the primary cooling loop, an FPS is actuated with a consequent plasma disruption, isolation of the secondary loop, and shutoff of the pumps in the primary; no other safety counteractions are postulated.

The objective of the work was to analyze the pressurization of the primary and secondary sides to show that the accidental overpressure in the two sides of the steam generators is safely accommodated. Furthermore, the effect of the plasma disruption on the FW, in terms of temperatures, should be analyzed. Lastly, the time transients of the pressures and temperatures in the HX and BB for a time span of up to $36 \mathrm{~h}$ should be obtained to assess the effect of the decay heat over a long period.

A full nodalization of the OTSG was realized together with a simplified nodalization of the whole PHTS BB loop. The code utilized was MELCOR for fusion version 1.8.6. The accident was simulated by activating a flow path which directly connected one section of the primary with the parallel section of the secondary side.

It was shown here that the pressures and the temperatures inside the whole PHTS system remained below the safety thresholds for the whole transient.

The only caveat of this analysis is due to the calculation of the effect of the decay heat, since the tables used for the estimation of this parameter referred to an old version of the WCLL-BB, as no other references are available on this issue.

It is believed that, for a fully comprehensive evaluation of the impact of the decay heat, a coupled calculation should be realized, connecting a nodalization of the FW PHTS loop and the PbLi loop with the nodalization of the BZ PHTS loop presented here.

Author Contributions: Conceptualization, F.G., M.M., A.P. and M.T.P.; methodology, F.G.; validation, F.G.; formal analysis, F.G.; investigation, F.G.; resources, N.F.; data curation, F.G.; writing-original draft preparation, F.G.; writing-review and editing, F.G., M.M., A.P., M.T.P. and N.F.; visualization, F.G.; supervision, M.T.P. and N.F.; project administration, M.T.P. and N.F.; All authors have read and agreed to the published version of the manuscript.

Funding: This research was funded by Euratom research and training program 2014-2018 and 2019-2020, grant number 633053.

Acknowledgments: This work was carried out within the framework of the EUROfusion Consortium and received funding from the Euratom research and training program 2014-2018 and 2019-2020 under grant agreement No 633053. The views and opinions expressed herein do not necessarily reflect those of the European Commission.

Conflicts of Interest: The authors declare no conflict of interest.

$\begin{array}{ll}\text { Abbreviations } \\ \text { ACP } & \text { Activate corrosion product } \\ \text { BB } & \text { Breeder blanket } \\ \text { BC } & \text { Boundary condition } \\ \text { BOP } & \text { Balance of plant } \\ \text { BSS } & \text { Back supporting structure } \\ \text { BZ } & \text { Breeder zone } \\ \text { CAD } & \text { Computer=aided design } \\ \text { CVH } & \text { Control volume hydrodynamics } \\ \text { DHR } & \text { Decay heat removal } \\ \text { DCD } & \text { Direct coupling design } \\ \text { DEMO } & \text { DEMOnstration power plant } \\ \text { FL } & \text { Flow path } \\ \text { FPS } & \text { Fast plasma shutdown }\end{array}$




$\begin{array}{ll}\text { FW } & \text { First wall } \\ \text { HT package } & \text { Heat structure package } \\ \text { IB } & \text { Inboard } \\ \text { LOCA } & \text { Loss of coolant accident } \\ \text { OB } & \text { Outboard } \\ \text { OTSG } & \text { Once through steam generator } \\ \text { PCS } & \text { Power conversion system } \\ \text { PHTS } & \text { Primary heat transport system } \\ \text { PbLi } & \text { Lead-lithium } \\ \text { PRZ } & \text { Pressurizer } \\ \text { VV } & \text { Vacuum vessel } \\ \text { VVPSS } & \text { Vacuum vessel pressure suppression system } \\ \text { WCLL } & \text { Water-cooled lithium lead } \\ \text { WPSAE } & \text { Work Package Safety and Environment }\end{array}$

\section{References}

1. Federici, G.; Bachmann, C.; Barucca, L.; Biel, W.; Boccaccini, L.; Brown, R.; Bustreo, C.; Ciattaglia, S.; Cismondi, F.; Coleman, M.; et al. DEMO design activity in Europe: Progress and updates. Fusion Eng. Des. 2018, 136, 729-741. [CrossRef]

2. Barucca, L.; Bubelis, E.; Ciattaglia, S.; D’Alessandro, A.; Del Nevo, A.; Giannetti, F.; Hering, W.; Lorusso, P.; Martelli, E.; Moscato, I.; et al. Pre-conceptual design of EU DEMO balance of plant systems: Objectives and challenges. Fusion Eng. Des. 2021, 169, 112504. [CrossRef]

3. Narcisi, V.; Ciurluini, C.; Giannetti, F.; Del Nevo, A. WCLL BB Phts Ddd (Direct Coupling Option with Small ESS). 2020. Report No.: IDM Ref. EFDA_D_2NURWJ. Available online: https://idm.euro-fusion.org/ (accessed on 13 October 2021).

4. Del Nevo, A.; Arena, P.; Caruso, G.; Chiovaro, P.; Di Maio, P.A.; Eboli, M.; Edemetti, F.; Forgione, N.; Forte, R.; Froio, A.; et al. Recent progress in developing a feasible and integrated conceptual design of the WCLL BB in EUROfusion project. Fusion Eng. Des. 2019, 146, 1805-1809. [CrossRef]

5. Zaupa, M.; Palma, M.D.; Del Nevo, A.; Moscato, I.; Tarallo, A.; Barucca, L. Preliminary Thermo-Mechanical Design of the Once Through Steam Generator and Molten Salt Intermediate Heat Exchanger for EU DEMO. IEEE Trans. Plasma Sci. 2020, 48, 1726-1732. [CrossRef]

6. Martelli, E.; Giannetti, F.; Ciurluini, C.; Caruso, G.; Del Nevo, A. Thermal-hydraulic modeling and analyses of the water-cooled EU DEMO using RELAP5 system code. Fusion Eng. Des. 2019, 146, 1121-1125. [CrossRef]

7. Ciurluini, C.; Giannetti, F.; Martelli, E.; Del Nevo, A.; Barucca, L.; Caruso, G. Analysis of the thermal-hydraulic behavior of the EU-DEMO WCLL breeding blanket cooling systems during a loss of flow accident. Fusion Eng. Des. 2021, 164, 112206. [CrossRef]

8. Merrill, B.; Moore, R.; Polkinghorne, S.; Petti, D. Modifications to the MELCOR code for application in fusion accident analyses. Fusion Eng. Des. 2000, 51-52, 555-563. [CrossRef]

9. Merrill, B.J. Recent Updates to the MELCOR 1.8. 2 Code for ITER Applications; Idaho National Laboratory (INL): Idaho Falls, ID, USA, 2007.

10. Merrill, B.J.; Humrickhouse, P.; Moore, R.L. A recent version of MELCOR for fusion safety applications. Fusion Eng. Des. 2010, 85, 1479-1483. [CrossRef]

11. D'Ovidio, G.; Martín-Fuertes, F. Accident analysis with MELCOR-fusion code for DONES lithium loop and accelerator. Fusion Eng. Des. 2019, 146, 473-477. [CrossRef]

12. Grief, A.; Owen, S.; Murgatroyd, J.; Panayotov, D.; Merrill, B.; Humrickhouse, P.; Saunders, C. Qualification of MELCOR and RELAP5 models for EU HCLL TBS accident analyses. Fusion Eng. Des. 2017, 124, 1165-1170. [CrossRef]

13. Panayotov, D.; Grief, A.; Merrill, B.J.; Humrickhouse, P.; Trow, M.; Dillistone, M.; Murgatroyd, J.T.; Owen, S.; Poitevin, Y.; Peers, K.; et al. Methodology for accident analyses of fusion breeder blankets and its application to helium-cooled pebble bed blanket. Fusion Eng. Des. 2015, 109-111, 1574-1580. [CrossRef]

14. Nakamura, M.; Tobita, K.; Someya, Y.; Utoh, H.; Sakamoto, Y.; Gulden, W. Safety research on fusion DEMO in Japan: Toward development of safety strategy of a water-cooled DEMO. Fusion Eng. Des. 2016, 109-111, 1417-1421. [CrossRef]

15. Pescarini, M.; Mascari, F.; Mostacci, D.; De Rosa, F.; Lombardo, C.; Giannetti, F. Analysis of unmitigated large break loss of coolant accidents using MELCOR code. J. Phys. Conf. Ser. 2017, 923, 012009. [CrossRef]

16. D'Onorio, M.; Giannetti, F.; Porfiri, M.T.; Caruso, G. Preliminary safety analysis of an in-vessel LOCA for the EU-DEMO WCLL blanket concept. Fusion Eng. Des. 2020, 155, 111560. [CrossRef]

17. D'Onorio, M.; Giannetti, F.; Porfiri, M.T.; Caruso, G. Preliminary sensitivity analysis for an ex-vessel LOCA without plasma shutdown for the EU DEMO WCLL blanket concept. Fusion Eng. Des. 2020, 158, 111745. [CrossRef]

18. Narcisi, V.; Giannetti, F.; Del Nevo, A. WCLL BB PHTS Architecture Description \& BOM (Direct Coupling Option with Small ESS). Report No.: IDM Ref. EFDA_D_2PC2N9. Available online: https://idm.euro-fusion.org/ (accessed on 13 October 2021).

19. Tarallo, A. WCLL BB PHTS CAD Model Description (Direct Coupling Option with Small ESS). Report No.: IDM Ref. EFDA_D_2P9QFM. 2020. Available online: https://idm.euro-fusion.org/ (accessed on 13 October 2021). 
20. Tarallo, A. WCLL BB PHTS Drawings (Direct Coupling Option with Small ESS). Report No.: IDM Ref. EFDA_D_2P95DT. 2020. Available online: https://idm.euro-fusion.org/ (accessed on 13 October 2021).

21. Tarallo, A. Preliminary Mechanical Design and Verification of WCLL BB PHTS Once through Steam Generator (OTSG). Report No.: IDM Ref EFDA_D_2MT7PL. 2020. Available online: https:/ / idm.euro-fusion.org/ (accessed on 13 October 2021).

22. Tarallo, A. WCLL OTSG CAD Model. Report No.: IDM Ref. UID 2NJQM8. 2020. Available online: https://idm.euro-fusion.org/ (accessed on 13 October 2021).

23. Catanzaro, I.; Arena, P.; Basile, S.; Bongiovì, G.; Chiovaro, P.; Del Nevo, A.; Di Maio, P.A.; Forte, R.; Maione, I.A.; Vallone, E. Structural assessment of the EU-DEMO WCLL Central Outboard Blanket segment under normal and off-normal operating conditions. Fusion Eng. Des. 2021, 167, 112350. [CrossRef]

24. Porfiri, M.T.; Mazzini, G. DEMO BB Safety Data List (SDL). Report No.: IDM Ref. EFDA_D_2MF8KU. 2018. Available online: https://idm.euro-fusion.org/ (accessed on 13 October 2021). 